\title{
Spectrophotometric Determination of Magnesium Oxide Content in Supplements of Magnesium
}

\author{
Š. Mandal, ${ }^{*}$ A. Alispahić, A. Dedić, and H. Džudžević-Čančar \\ University of Sarajevo, Faculty of Pharmacy, Department of Natural Sciences in Pharmacy \\ Zmaja od Bosne 8 (Campus), 71000 Sarajevo, Bosnia and Herzegovina
}

This work is licensed under

\begin{abstract}
Magnesium is an essential element and the intracellular divalent cation involved in many biochemical functions. People with magnesium deficiency must increase their intake of magnesium, usually in the form of various supplements. A common form of magnesium supplement widely available in pharmacies is magnesium oxide (MgO). In this work, the content of MgO was determined in pharmaceutical supplementations using spectrophotometry, based on the reaction between magnesium ions and eriochrome black T at a wavelength of $535 \mathrm{~nm}$. The analysed content of $\mathrm{MgO}$ ranged from 360.5 to $386.5 \mathrm{mg} \mathrm{MgO}$, which corresponds to the daily Mg recommended values (300 to $400 \mathrm{mg}$ ).
\end{abstract}

\section{Keywords}

Magnesium, magnesium oxide, supplementation

\section{Introduction}

Magnesium is a major cation in the human body involved in many chemical and physiological functions, including synthesis of fatty acids and proteins, metabolism of diet, and transmission of nerve impulses. It is a cofactor for more than 300 metabolic reactions in the body. These processes include protein synthesis, cellular energy production and storage, cell growth and reproduction, DNA and RNA synthesis, and stabilization of mitochondrial membranes. Therefore, magnesium plays an important role in disease prevention and human health. ${ }^{1-7}$

Low levels of magnesium, i.e. hypomagnesemia, have been associated with a number of chronic diseases including migraine headaches, Alzheimer's disease, stroke, cardiovascular disease, and Type 2 diabetes. People with magnesium deficiency must increase their intake of magnesium, usually in the form of various pharmaceutical supplements. ${ }^{8-13}$ Magnesium oxide is a common form of magnesium supplement that is widely available in pharmacies because it is less expensive than other forms (i.e. citrate, chloride, and amino acid gluconate). Moreover, magnesium oxide contains about $60 \%$ elemental magnesium. Another reason could be the differences in the bioavailability between different magnesium salts. Good solubility of magnesium salts in water is important for its bioavailability. The studies demonstrate that organic Mg salts have a higher solubility than inorganic salts. ${ }^{14,15}$

Several reagents in colorimetric as well as spectrophotometric methods for the determination of magnesium have been described in the literature, such as eriochrome black

* Corresponding author: Šaćira Mandal, Associate Professor, PhD Email: sacira.mandal@ffsa.unsa.ba
T (EBT), titan yellow (TY), ammonium phosphate method, ethylenediaminetetraacetic acid (EDTA), paratolyl-2-thenohydroxamic acid and quinalizarin, 4-methyl-3-((1-HIndol-3-iyl)(phenyl)methyl)-1-H-Indol (MPBIM), and trizma-chloranilate. ${ }^{16-21}$ All of these procedures require a true solution of a coloured magnesium complex in which the colour intensity is directly proportional to the magnesium concentration.

The aim of this work was to determine the total content of magnesium oxide in supplements from different manufacturers available in pharmacies in Sarajevo using modified spectrophotometric method. Modification was aimed at shortening the time of colour development by addition of solid EBT instead of its solution. Thus, the problems associated with EBT in the form of an unstable solution were prevented. This modification changes none of the parameters of standard eriochrome black T method.

\section{Experimental}

The magnesium supplements (a common form of magnesium as magnesium oxide, $\mathrm{MgO}$ ) of various manufacturers were bought from pharmacies in Sarajevo, as follows: Maxi Mag-magnezijum 375 mg+Vitamin B6 (NATUR PRODUCT PHARM), Magnezium-Lek ${ }^{\circledR}$ Direkt (SANDOZ), MagnEasyum Forte (MINERALI ZDRAVLJA) with declared contents of magnesium in tablets as $375 \mathrm{mg}, 300 \mathrm{mg}$, and $400 \mathrm{mg}$, respectively. For analysis, the supplements were marked as Sample I, Sample II, and Sample III.

Total content of magnesium oxide (MgO) of each supplement was determined by spectrophotometry, in triplicate, using minor modified eriochrome black T (EBT) method. ${ }^{17}$ 


\subsection{Sample preparation}

Samples of tested $\mathrm{MgO}$ supplements (0.30 g each) were dissolved in $1.0 \mathrm{ml}$ of $6 \mathrm{M}$ hydrochloric acid, and diluted with distilled water to mark $(50 \mathrm{ml})$. Working solutions of all samples $(5.0 \mathrm{ml})$ were prepared in triplicate, and measured with a "Spectronic Genesys 2" spectrophotometer (Thermo Electron Corporation, Madison, USA) after complexation of $\mathrm{Mg}^{2+}$ ions with EBT (Sodium 1-[1-Hydroxynaphthylazo]-6-nitro-2-naphthol-4-sulfonate) in an ammonia buffer.

\subsection{Reagent and standard solutions preparation}

All reagents were of analytical grade (p.a.), while distilled water (Milli-Q, Millipore) was used for samples dilution and labware washing. Solutions of eriochrome black $T$ method, EBT (Merck, Germany) are unstable even when freshly prepared and thus useless for complexation and formation of analyte dye (with $\mathrm{Mg}^{2+}$ ions). Therefore, EBT was added directly to the analysed and standard solutions, precisely weighed to $0.1 \mathrm{~g}$ of salt during analysis and construction of calibration curve. Standard stock solution $\left(\gamma\left(\mathrm{Mg}^{2+}\right)=1 \mathrm{mg} \mathrm{ml}^{-1}\right)$ of magnesium (II) ions was prepared by dissolving $0.4180 \mathrm{~g}$ of magnesium (II) chloride (Sigma-Aldrich Co. LLC) in a few $\mathrm{mL}$ of $6 \mathrm{M}$ hydrochloric acid (Merck, Darmstadt, Germany), and diluted with deionized water in a volumetric flask $(50 \mathrm{ml})$.

The calibration solutions were prepared by pipetting aliquots of $0.05,0.10,0.25,0.50,0.75,1.00,1.50,2.00$, and $2.50 \mathrm{ml}$, respectively, of the stock standard solution into volumetric flasks $(10 \mathrm{ml})$, then, to each volumetric flask, adding $1.00 \mathrm{~mL}$ of ammonia buffer, $0.1 \mathrm{~g}$ of EBT and distilled water to obtain a concentration range of $\mathrm{Mg}$ from 0.0383 to $0.2049 \mathrm{mmol} \mathrm{ml}^{-1}$. Ammonia buffer solution was prepared by dissolving $54.0 \mathrm{~g}$ of ammonia chloride in $200 \mathrm{~mL}$ of water, and adding $350 \mathrm{~mL}$ of $10 \mathrm{M}$ ammonia, then diluting it with water to $1000 \mathrm{ml}$.

The absorbance of each working solution was measured at absorption maximum of $535 \mathrm{~nm}$ using $10 \mathrm{~mm}$ quartz cuvette (Fig. 1).

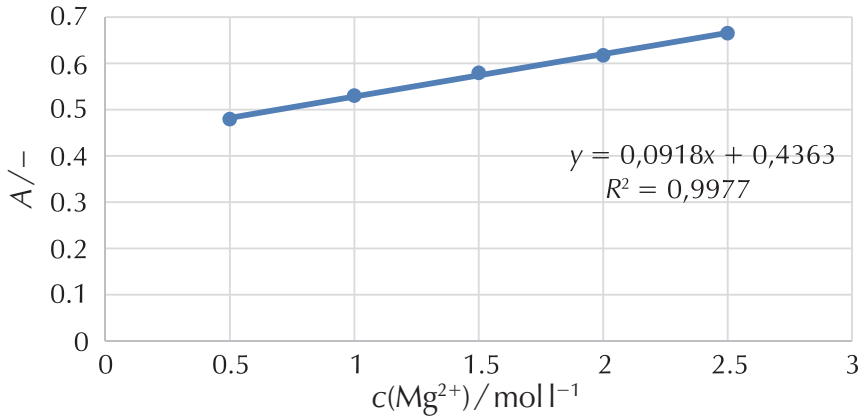

Fig. 1 - Calibration curve

Slika 1 - Kalibracijska krivulja

\subsection{Total $\mathrm{MgO}$ content determination}

For determination of magnesium oxide content in selected commercially available pharmaceutical supplements of magnesium, working solutions of all nine samples were treated with EBT and ammonia buffer as mentioned above for standard stock solutions of $\mathrm{Mg}^{2+}$ ions. Reaction between magnesium ions and eriochrome black $\mathrm{T}$ is favourable in basic medium $(\mathrm{pH}=10)$ and room temperature; therefore, an ammonia buffer was added, and measurement was performed on a wavelength of $535 \mathrm{~nm}$. Working wavelength was chosen by analysing the spectrogram obtained by measuring absorbance $A$ in function of wavelength, $\lambda$ as the maximum wavelength gives the best sensitivity and accuracy. The optimal wavelength $\left(\lambda_{\max }\right)$ for measuring absorbance is the wavelength that is most absorbed by the analyte in question. Practically, measurements made by scanning the absorbance of standard solution colour intensity enabled us to observe the maximum peak at which the highest absorbance was recorded.

In neutral or somewhat basic solutions (i.e., $\mathrm{pH}=10$ ), eriochrome black $\mathrm{T}$ is a double dissociated ion, $\mathrm{HIn}^{2-}$, which is blue in colour. When this free form of EBT reacts with magnesium ions, a pink coloured complex is formed (Fig. 2).<smiles>O=[N+]([O-])c1ccc2c(/N=N/c3ccc4ccccc4c3O)c(O)cc([S+](=O)[O-])c2c1</smiles>

free indicator $\left(\mathrm{H}_{2} \mathrm{In}^{-}\right)$<smiles>[14CH3]Oc1cc(S)c2cc([N+](=O)[O-])ccc2c1/N=N/c1ccc2ccccc2c1O[14CH3]</smiles>

$\mathrm{Mg}^{2+}$ indicator complex $\left(\mathrm{Mgln}^{-}\right)$

blue

pink

Fig. 2 - Reaction between magnesium ions and eriochrome black T

Slika 2 - Reakcija između magnezijevih iona i eriokrom crnog T 


\section{Results and discussion}

Spectrophotometric analysis was carried out with EBT as an easily available and low cost indicator. In addition, we simplified the colouration of analysed samples and stability of Mg-EBT complex by adding solid salt and avoiding longterm addition of freshly prepared EBT solution to each individual solution of working and analysed samples.

The daily intake requirement in adults is about $400 \mathrm{mg}$, but when used as a treatment, magnesium is often recommended at doses of 250 to $600 \mathrm{mg}$ for adults. Comparison of the recommended intake doses with the $\mathrm{MgO}$ content declared and measured in selected commercially available samples, showed good agreement. The analysed content of $\mathrm{MgO}$ in the three supplements of various manufacturers available in pharmacies in Sarajevo ranged from 290.4 to $398.5 \mathrm{mg} \mathrm{MgO}$. Results are presented in Table 1 as mean \pm SD for Sample I, Sample II, and Sample III, respectively.

Table 1 - Total content of MgO in analysed supplements

Tablica 1 - Ukupni sadržaj MgO u analiziranim pripravcima

\begin{tabular}{c|c|c}
\hline $\begin{array}{c}\text { Components } \\
\text { Komponente }\end{array}$ & $\begin{array}{c}\text { Analysed content } \\
\text { of } \mathrm{MgO}^{*}\end{array}$ & $\begin{array}{c}\text { Declared content } \\
\text { of } \mathrm{MgO}\end{array}$ \\
\hline Sample I, mg MgO & $374.7 \pm 5.5$ & 375 \\
Sample II, mg MgO & $290.4 \pm 1.3$ & 300 \\
Sample III, mg MgO & $398.5 \pm 5.3$ & 400 \\
\hline
\end{tabular}

* Data presented as mean $\pm \mathrm{SD}$

As may be seen from Table 1, the difference between declared and true MgO content was lowest in Sample III. Although the other two measured samples showed no significant deviations, all three analysed samples in a single capsule dose contain approximately the recommended daily dose of magnesium in the form of magnesium oxide.

Nowadays, magnesium in the form of magnesium oxide is used as a dietary supplement for various disorders and medical conditions, such as neurological (migraine, insomnia, Alzheimer disease, etc.), vascular disease (hypertension, stroke, CVD, CAD), diabetes and prediabetes, during pregnancy, etc. ${ }^{1,4,22-26}$

\section{Conclusion}

Commercially available Mg-supplements in pharmacies in Sarajevo were tested with the purpose of determining the $\mathrm{MgO}$ content. Based on the obtained results, the conclusions can be drawn as follows: the analysed supplements of $\mathrm{MgO}$ commonly used, can be considered as a good source of magnesium in pharmaceutical products, as they showed that the declared value of $\mathrm{MgO}$ corresponds with recommended daily doses. In addition, sample preparation, complexation of magnesium ions with solid EBT, and spectrophotometric measurement are simple, not time consuming and applicable for determination of $\mathrm{MgO}$ in commercial supplements.

\section{List of abbreviations and symbols Popis kratica i simbola}

\author{
EBT - eriochrome black T \\ - eriokrom crnog T \\ TY - titan yellow \\ - indikator titan žuto \\ EDTA - ethylenediaminetetraacetic acid \\ - etilendiamintetraoctena kiselina \\ MPBIM- 4-methyl-3-((1-H-Indol-3-iyl)(phenyl)methyl)-1-H- \\ -Indol \\ - 4-metil-3-((1-H-indol-3-il)(fenil)metil)-1-H-indol
}

\section{References \\ Literatura}

1. M. P. Guerrera, S. L. Volpe, J. J. Mao, Therapeutic uses of magnesium, Am. Fam. Physician. 80 (2) (2009) 157-162, doi: https://www.aafp.org/afp/2009/0715/p157.pdf.

2. F. de Baaij, J. Hoenderop, M. Bindels, Magnesium in man: implications for health and disease, Physiol Rev. 95 (2015) 1-46, doi: https://doi.org/10.1152/physrev.00012.2014.

3. J. Hoenderop, M. Bindels, Epithelial $\mathrm{Ca}^{2+}$ and $\mathrm{Mg}^{2+}$ channels in health and disease, J. Am. Soc. Nephrol. 16 (2005) 15-26, doi: https://doi.org/10.1681/ASN.2004070523.

4. M. Makrides, D. D. Cosby, E. Bain, C. A. Crowther, Magnesium supplementation in pregnancy, Cochrane Database Syst. Rev. 4 (2014) 1-43, doi: https://doi.org/10.1002/14651858. CD000937.pub2.

5. A. M. P. Romani, Magnesium in Health and Disease. (Met. Ions Life Sci. 13. Chapter 3, Springer Science+Business Media Dordrecht, 2014, pp. 5-28.

6. M. Tatsuki, R. Miyazawa, T. Tomomasa, T. Ishige, T. Nakazawa, H. Arakawa, Serum magnesium concentration in children with functional constipation treated with magnesium oxide, World J. Gastroenterol. 17 (6) (2011) 779-783, doi: https://doi.org/10.3748/wjg.v17.i6.779.

7. S. L. Volpe, Magnesium in Disease Prevention and Overall Health, Adv. Nutr. 4 (2013) 378S-383S, doi: https://doi. org/10.3945/an.112.003483.

8. J. Vormann, Magnesium and Kidney Health - More on the 'Forgotten Electrolyte', Am. J. Nephrol. 44 (2016) 379-380, doi: https://doi.org/10.1159/000450863.

9. Food and Nutrition Board, Institute of Medicine. (1997). Dietary Reference Intakes for calcium, phosphorus, magnesium, vitamin D, and fluoride, Washington, DC: National Academies Press.

10. M. Shechter, T. Saad, A. Shechter, N. Koren-Morag, B. B. Silver, $S$. Matetzky, Comparison of magnesium status using X-ray dispersion analysis following magnesium oxide and magnesium citrate treatment of healthy subjects, Magnes. Res. 25 (1) (2012) 28-39, doi: https://doi.org/10.1684/mrh.2012.0305.

11. S. M. Alghadeer, The efficacy of different oral magnesium supplements for migraine prevention: a literature review, Indones. J. Pharm. 27 (3) (2017) 174-182, doi: https://doi. org/10.14499/indonesianjpharm27iss3pp174. 
12. A. R. Cunha, B. Umbelino, M. L. Correia, M. Fritisch Neves, Magnesium and vascular changes in hypertension, Int. J. Hypertension Article ID 754250 (2012) 1-7, doi: https://doi. org/10.1210/jc.2006-1391.

13. X. Fang, K. Wang, D. Han, X. He, J. Wei, L. Zhao, M. U. Imam, Z. Ping, Y. Li, Y. Xu, J. Min, F. Wang, Dietary magnesium intake and the risk of cardiovascular disease, type 2 diabetes, and all-cause mortality: a dose-response metaanalysis of prospective cohort studies, BMC Med. 14 (210) (2016) 1-13, doi: https://doi.org/10.1186/s12916-016-0742-z.

14. V. D. Felice, D. M. O`Gorman, N. M. O`Brien, N. P. Hyland, Bioaccessibility and bioavailability of a marine-derived multimineral, aquamin-magnesium, Nutrients 10 (2018) 912920, doi: https://doi.org/10.3390/nu10070912.

15. R. Rylander, Bioavailability of Magnesium Salts - A Review, J. Pharm. Nutrit. Sci. 4 (1) (2014) 57-59, doi: https://www. ncbi.nlm.nih.gov/pubmed/16548135.

16. A. Shokrollahi, K. Hemmatidoust, F. Zarghapmour, Science direct determination of magnesium by the solution scanometric method in a coloured titan yellow magnesium hydroxide complex form, J. Taibah Univ. Sci. 10 (2016) 161167, doi: https://doi.org/10.1016/j.jtusci.2015.08.003.

17. A. E. Harvey Jr., J. M. Komarmy, G. M. Wyatt, Colorimetric determination of magnesium with eriochrome black T, Anal. Chem. 25 (1953) 498-500, doi: https://pubs.acs.org/doi/ pdf/10.1021/ac60075a031.

18. F. W. Heaton, Determination of magnesium by the titan yellow and ammonium phosphate methods, J. Clin. Pathol. 13 (1960) 358-360, doi: https://www.ncbi.nlm.nih.gov/pmc/ articles/PMC480095/pdf/jclinpath00057-0080.pdf

19. M. Lei, L. Chen, B. Huang, K. Chen, Determination of Magnesium Oxide Content in Mineral Medicine Talcum Using Near-Infrared Spectroscopy Integrated with Support Vector Machine, Appl. Spectroscopy. 71 (11) (2017) 2427-2437, doi: https://doi.org/10.1177/0003702817727016.
20. L. L. Lewis, L. M. Melnick, Determination of calcium and magnesium with (ethylenedinitrilo) tetraacetic acid. Studies in accuracy, Anal. Chem. 32 (1960) 38-42, doi: https://pubs. acs.org/doi/abs/10.1021/ac60157a011.

21. N. Dallali, Y. K. Agrawal, Solvent extraction and spec-trophotometric determination of magnesium by paratolyl-2-thenohydroxamic acid and quinalizarin, Iran. J. Chem. Chem. Eng. 23 (2004) 65-72, doi: https://www.ijcce.ac.ir/article_8162_ a22ac89de27cb30dd62e117ba2d874b8.pdf.

22. W. Li, X. Zhu, Y. Song, L. Fan, L. Wu, E. K. Kabagambe, L. Hou, M. J. Shrubsole, J. Liu, Q. Dai, Intakes of magnesium, calcium and risk of fatty liver disease and prediabetes, Public Health Nutrition 21 (11) (2018) 2088-2095, doi: https://doi. org/10.1017/S1368980018000642.

23. L. Wu, X. Zhu, L. Fan, E. K. Kabagambe, Y. Song, M. Tao, X. Zhong, L. Hou, M. J. Shrubsole, J. Liu, Q. Dai, Magnesium intake and mortality due to liver diseases: Results from the Third National Health and Nutrition Examination Survey Cohort, Sci. Rep. 7 (17913) (2017) 1-6, doi: https://www. nature.com/articles/s41598-017-18076-5.

24. B. Abbasi, M. Kimiagar, K. Sadeghniiat, M. M. Shirazi, M. Hedayati, B. Rashidkhani, The effect of magnesium supplementation on primary insomnia in elderly: a doubleblind placebocontrolled clinical trial, J. Res. Med. Sci. 17 (12) (2012) 1161-1169, doi: https://www.ncbi.nlm.nih.gov/pmc/ articles/PMC3703169/.

25. T. O. Carpenter, M. C. DeLucia, J. Hongyuan Zhang, G. Bejnerowicz, L. Tartamella, J. Dziura, K. Falk Petersen, D. Befroy, D. Cohen, A randomized controlled study of effects of dietary magnesium oxide supplementation on bone mineral content in healthy girls, J. Clin. Endocrinol. Metabol. 91 (12) (2006) 4866-4872, doi: https://doi.org/10.1210/jc.2006-1391.

26. 26. A. A. Carson, Magnesium oxide supplements for the treatment of post-chemotherapy sleep disturbance, J. Clin. Oncol. 35 (5) (2017) 175-175, doi: https://doi.org/10.1200/ JCO.2017.35.5_suppl.175.

\title{
SAŽETAK
}

\section{Spektrofotometrijsko određivanje sadržaja magnezijeva oksida u pripravcima s magnezijem

\author{
Šaćira Mandal, Amra Alispahić, Alema Dedić i Hurija Džudžević-Čančar
}

\begin{abstract}
Magnezij je esencijalni element i intrastanični dvovalentni kation uključen u više biokemijskih funkcija. Osobe s manjkom magnezija moraju ga dodatno unositi i to često u obliku različitih pripravaka. Magnezijev oksid (MgO) najčešći je oblik pripravka s magnezijem koji je široko dostupan u ljekarnama. U ovom radu spektrofotometrijom je određen sadržaj MgO u farmaceutskim dodatcima temeljen na reakciji između magnezijevih iona i eriokrom crnog T na valnoj duljini od 535 nm. Analizirani sadržaj MgO kretao se u rasponu od 360,5 do 386,5 mg MgO, što odgovara dnevnim preporučenim vrijednostima unosa Mg (300 do $400 \mathrm{mg}$ ).
\end{abstract}

Ključne riječi

Magnezij, magnezijev oksid, suplementacija

Univerzitet u Sarajevu

Farmaceutski fakultet

Zmaja od Bosne 8 (kampus)

71000 Sarajevo

Bosna i Hercegovina
Izvorni znanstveni rad Prispjelo 11. prosinca 2018. Prihvaćeno 18. ožujka 2019. 